Philadelphia March ACS meeting 2020 Posters

\title{
Creation of Amino Acid Metallocene 4 Polymers to Combat Cancer
}

Paul Slawek, Francesca Mosca, Charles E. Carraher, Jr., Michael R. Roner, Jerome E. Haky

Abstract: Amino acid containing polymers were synthesized from reaction of diglycine and group 4 metallocene dihalides employing the interfacial condensation process in decent yield and chain lengths. Yield increases as the metallocene metal weight increases consistent with the hard/soft acid theory. Chain length decreases as the metallocene weight increases. Infrared, MALDI MS, and NMR results are consistent with the proposed repeat unit. The polymers exhibit good inhibition of all cell lines tested including two pancreatic, two brain, two breast, prostate and lung human cancer cell lines.

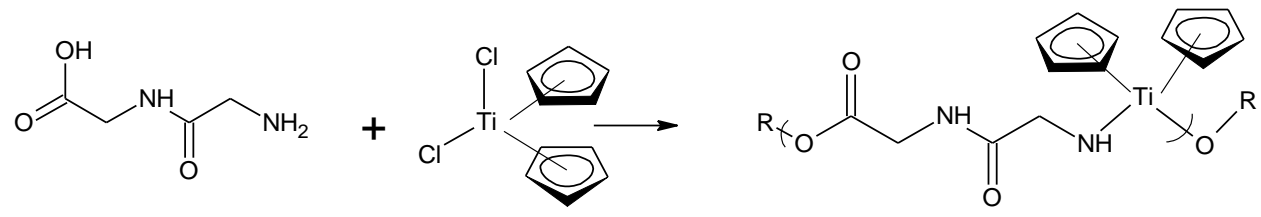

Paul and Francesca-we have plenty of time. Will need to get maldi ms and nmr and ir. Paper is given in March 2020.

\begin{tabular}{|l|l|l|l|}
\hline $\begin{array}{l}\text { Metallocene } \\
\text { Dichloride }\end{array}$ & Yield (\%) & Molecular Weight & Chain Length \\
\hline Titanocene & 32 & $7.1 \times 10^{6}$ & 2300 \\
\hline Zirconocene & 48 & $3.8 \times 10^{6}$ & 1800 \\
\hline Hafnocene & 68 & $2.8 \times 10^{6}$ & 630 \\
\hline
\end{tabular}

The polymers exhibit good inhibition of all of the cell lines studied. The diglycine exhibited no inhibition. The metallocene monomers exhibited little inhibition of the brain cancer cells while the metallocene monomers showed good inhibition of the other cancer cell lines. Typically, the polymers showed greater inhibition of the cell lines compared with the metallocene monomers. The CI values were typically one and greater for both the metallocene monomers and polymers. 
Table 1. Metallocene results for Diglycine

\begin{tabular}{|c|c|c|c|c|c|}
\hline Sample & $3 \mathrm{~T} 3$ & WI-38 & PANC-1 & AsPC-1 & PC3 \\
\hline $\mathrm{Cp}_{2} \mathrm{TiCl}_{2}$ & $1.8(.2)$ & $2.2(.1)$ & $0.45(.3)$ & $0.51(.05)$ & $0.48(.05)$ \\
\hline $\mathrm{Cp}_{2} \mathrm{Ti} / \mathrm{DG}$ & $0.66(.1)$ & $0.66(.1)$ & $0.50(.1)$ & $0.61(.1)$ & $0.60(0.1)$ \\
\hline $\mathrm{Cp}_{2} \mathrm{ZrCl}{ }_{2}$ & $1.8(.2)$ & $0.94(.1)$ & $0.38(.3)$ & $0.44(.05)$ & $0.25(.03)$ \\
\hline $\mathrm{Cp}_{2} \mathrm{Zr} / \mathrm{DG}$ & $0.70(.1)$ & $0.79(.1)$ & $0.79(.1)$ & $0.79(.1)$ & $0.75(.1)$ \\
\hline $\mathrm{Cp}_{2} \mathrm{HfCl}{ }_{2}$ & $1.7(.2)$ & $1.2(.2)$ & $0.22(.2)$ & $0.18(.01)$ & $0.25(.03)$ \\
\hline $\mathrm{Cp}_{2} \mathrm{Hf} / \mathrm{DG}$ & $0.78(.1)$ & $0.72(.1)$ & $0.71(.1)$ & $0.77(.1)$ & $0.74(.1)$ \\
\hline Diglycine & $>2.0$ & $>2.0$ & $>2.0$ & $>2.0$ & $>2.0$ \\
\hline Cisplatin & $0.015(.01)$ & $0.019(.01)$ & $.0023(.005)$ & $.0035(.005)$ & $0.0044(.004)$ \\
\hline
\end{tabular}

\begin{tabular}{|c|c|c|c|c|c|}
\hline Sample & MDA-MB & HT-29 & MCF-7 & U251 & G56 \\
\hline $\mathrm{Cp}_{2} \mathrm{TiCl}_{2}$ & $0.35(.05)$ & $0.54(.06)$ & $0.47(.05)$ & $>2.0$ & $>2.0$ \\
\hline $\mathrm{Cp}_{2} \mathrm{Ti} / \mathrm{DG}$ & $0.56(.1)$ & $0.56(.1)$ & $0.64(.1)$ & $0.77(.2)$ & $0.62(.2)$ \\
\hline $\mathrm{Cp}_{2} \mathrm{ZrCl}{ }_{2}$ & $0.27(.03)$ & $0.31(.02)$ & $0.33(.05)$ & $>2.0$ & $>2.0$ \\
\hline $\mathrm{Cp}_{2} \mathrm{Zr} / \mathrm{DG}$ & $0.66(.1)$ & $0.72(.1)$ & $0.67(.1)$ & $0.40(.1)$ & $0.61(9.1)$ \\
\hline $\mathrm{Cp}_{2} \mathrm{HfCl}$ & $0.27(.03)$ & $0.31(.02)$ & $0.33(.05)$ & $>2.0$ & $>2.0$ \\
\hline $\mathrm{Cp}_{2} \mathrm{Hf} / \mathrm{DG}$ & $0.66(.1)$ & $0.53(.1)$ & $0.67(.1)$ & $0.66(.1)$ & $0.63(.1)$ \\
\hline Diglycine & $>2.0$ & $>2.0$ & $>2.0$ & $>2.0$ & $>2.0$ \\
\hline Cisplatin & $0.0029(.002)$ & $0.0041(.003)$ & $0.0057(.003)$ & $0.015(.01)$ & $0.20(.01)$ \\
& & & & & \\
\hline
\end{tabular}

Table 2. CI results as a function of cancer cells.

\begin{tabular}{|c|c|c|c|c|}
\hline Sample & $\begin{array}{c}\text { EC50WI-38/ } \\
\text { EC50PNC-1 }\end{array}$ & $\begin{array}{c}\text { EC50WI-38/ } \\
\text { EC50AsPC-1 }\end{array}$ & $\begin{array}{c}\text { EC50WI-38/ } \\
\text { EC50PC-3 }\end{array}$ & $\begin{array}{c}\text { EC50WI-38/ } \\
\text { EC50MDA }\end{array}$ \\
\hline $\mathrm{Cp}_{2} \mathrm{TiCl}_{2}$ & 4.9 & 4.3 & 4.6 & 6.3 \\
\hline $\mathrm{Cp}_{2} \mathrm{Ti} / \mathrm{DG}$ & 1.3 & 1.1 & 1.1 & 1.2 \\
\hline $\mathrm{Cp}_{2} \mathrm{ZrCl}{ }_{2}$ & 2.5 & 2.1 & 3.8 & 3.5 \\
\hline $\mathrm{Cp}_{2} \mathrm{Zr} / \mathrm{DG}$ & 1.0 & 1.0 & 1.1 & 1.2 \\
\hline $\mathrm{Cp}_{2} \mathrm{HfCl}$ & & 4.8 & 4.4 \\
\hline $\mathrm{Cp}_{2} \mathrm{Hf} / \mathrm{DG}$ & 5.5 & 6.7 & 0.97 & 1.1 \\
\hline $\mathrm{Cisplatin}$ & 1.0 & 0.94 & 4.4 & 6.6 \\
\hline
\end{tabular}

\begin{tabular}{|c|c|c|c|c|}
\hline Sample & $\begin{array}{c}\text { EC50 WI-38/ } \\
\text { EC50HT-29 }\end{array}$ & $\begin{array}{c}\text { EC50 WI-38/ } \\
\text { EC50MCF-7 }\end{array}$ & $\begin{array}{c}\text { EC50 WI-38/ } \\
\text { EC50 } \mathbf{2 5 1}\end{array}$ & $\begin{array}{c}\text { EC50 WI-38/ } \\
\text { EC50G55 }\end{array}$ \\
\hline $\mathrm{Cp}_{2} \mathrm{TiCl}_{2}$ & 4.1 & 4.7 & $<0.62$ & $<0.62$ \\
\hline $\mathrm{Cp}_{2} \mathrm{Ti} / \mathrm{DG}$ & 1.2 & 1.2 & 0.86 & 1.1 \\
\hline $\mathrm{Cp}_{2} \mathrm{ZrCl}_{2}$ & 3.0 & 2.8 & $<0.47$ & $<0.47$ \\
\hline $\mathrm{Cp}_{2} \mathrm{Zr} / \mathrm{DG}$ & 1.1 & 1.1 & 2.0 & 1.3 \\
\hline $\mathrm{Cp}_{2} \mathrm{HfCl}$ & 3.6 & $<0.60$ & $<0.60$ \\
\hline $\mathrm{Cp}_{2} \mathrm{Hf} / \mathrm{DG}$ & 3.9 & 1.1 & 1.1 & 1.1 \\
\hline $\mathrm{Cisplatin}$ & 4.4 & 3.3 & 0.80 & 0.57 \\
\hline
\end{tabular}




\begin{tabular}{|l|l|l|l|l|l|}
\hline Metallocene & WI-38 & U251 & G55 & CI U251 & CI G55 \\
\hline Titanocene/DG & 0.664 & 0.767 & 0.614 & 0.86 & 1.1 \\
\hline Zirconocene/DG & 0.782 & 0.400 & 0.609 & 2.0 & 1.3 \\
\hline Hafnocene/DG & 0.724 & 0.659 & 0.633 & 1.1 & 1.1 \\
\hline
\end{tabular}

\section{Reaction of thymidine and group 4 metallocene dihalides producing synthetic nucleic acids and their ability to inhibit human cancer cell lines.}

Jessica Frank, Charles E. Carraher, Jr., Michael R. Roner, Kimberly Shahi, Paul Slawek, Francesca Mosca, Anna Zamora, Anuj H. Patel, Sahar Jafri, Pooja Thaker, Frederick Fox IV, Yadnar Rigaud, Daniyal Hashmi

\footnotetext{
ABSTRACT: The initial synthesis of zirconocene polymers from zirconocene dichloride and nucleosides (thymidine) using commercially available reagents is described. Synthesis was carried out using simple Lewis acid-base reactions in accordance with hard-soft acid base theory, with zirconium as a hard acid and thymidine as a hard base. Light scattering techniques were employed for the initial characterization of this synthetic nucleic acid-like polymer and are consistent with the zirconocene-type structure. The polymeric material was obtained in moderate yield, with a molecular weight of $1.2 \times 10^{5}$, containing 461 repeat units, and a total chain length of 260. Preliminary screening for biological activity indicates satisfactory inhibition of a variety of cancer cell lines including PANC-1 and AsPC-1, two pancreatic and two glioblastomas brain cancer cell lines. Preliminary data obtained for pharmacodynamic properties on tested cancer cell
} 
lines suggests that inhibition of certain lines including pancreatic and glioblastomas cancer cell lines displayed favorable inhibition at concentrations in the nano-range.

Jessica, Paul and Francesca-need nmr for this and we will have sufficient to get a paper out of what else we have. Jessica, there is too much here to make your poster, but better to have too much than not enough.

The first patent for the chemical synthesis of nucleic acids was by Carraher and Millich. ${ }^{[1]}$ This was followed by describing the synthesis of synthetic nucleic acids from thymidine and 2-deoxy-D-ribose in $1971^{[2]}$ and additional related syntheses of nucleic acid-like polymers. ${ }^{[3-7]}$ More recently, we have focused on metal-containing polymers for various reasons including biological inhibition of unwanted agents including viruses, bacteria, fungi and cancer. Here the synthesis of group 4 metallocene-containing synthetic acids is described.<smiles>Cc1cn(C2CC(O)C(CO)O2)c(=O)[nH]c1=O</smiles>

Structure of thymidine.

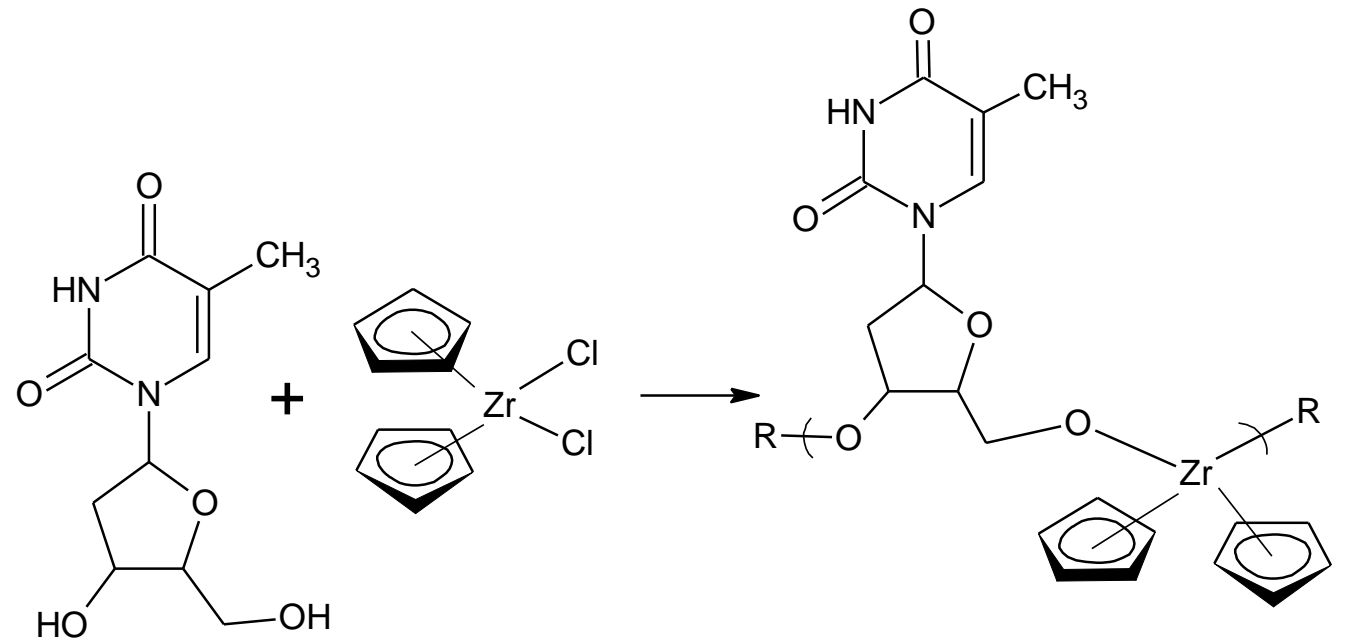

Repeat unit for the product from thymidine and zirconocene dichloride. 


\section{EXPERIMENTAL Reactions and Reactants}

Reactions were carried out using the interfacial polycondensation technique. Briefly, an aqueous solution $(30 \mathrm{ml})$ containing the thymidine $(0.00300 \mathrm{~mol})$ and sodium hydroxide $(0.0060$ mol) was transferred to a one quart Kimax emulsifying jar fitted on top of a Waring Blender (model 1120; no load speed of about 18,000 rpm; reactions were carried out at room temperature, at about $25{ }^{\circ} \mathrm{C}$ ). Stirring was begun and a heptane solution (30 $\mathrm{ml})$ containing the metallocene dichloride $(0.00300 \mathrm{~mol})$ was rapidly added (about 3-4 seconds) through a hole in the jar lid using a powder funnel. The resulting solution was blended for 15 seconds. The precipitate was recovered using vacuum filtration and washed several times with deionized water and heptane to remove unreacted materials and unwanted by-products. The solid was washed onto a glass petri dish and allowed to dry at room temperature.

Titanocene dichloride (1271-19-8), thymidine (50-89-5), and zirconocene dichloride (1291-32-3) were purchased from Aldrich Chemical Co., Milwaukee, WS; and hafnocene dichloride (12116-66-4) was obtained from Ventron Alfa Inorganics, Beverly, Mass. The reactants were used as received.

\section{Physical Characterization}

Light scattering photometry was carried out employing a Brice-Phoenix Universal Light Scattering Photometer Model 4000. Infrared spectra were obtained employing attenuated total reflectance infrared spectroscopy utilizing a JASCO FT/IR-4100 fitted with an ATR Pro 450-s.

High resolution electron impact positive ion matrix assisted laser desorption ionization time of flight, HR MALDI-TOF, mass spectrometry was carried out employing a Voyager-DE STR BioSpectrometer, Applied Biosystems, Foster City, CA. The standard settings were used with a linear mode of operation and an accelerating voltage of 25,000 volts; grid voltage $90 \%$ and an acquisition mass range of 2000 to 100,000. Fifty to two hundred shots were typically taken for each spectrum. Results employing alpha-cyano-4hydroxycinnamic acid are included in the present paper. The solid product along with solid matrix were mixed together employing copper spheres giving a fine powder that was employed to obtain the spectra. Infrared spectra were obtained employing attenuated total reflectance infrared spectroscopy utilizing a JASCO FT/IR-4100 fitted with an ATR Pro 450-s. ${ }^{1} \mathrm{H}$ NMR spectra were obtained in d-6 DMSO employing Varian Inova 400 $\mathrm{MHz}$ and Varian $500 \mathrm{MHz}$ spectrometers.

\section{Cell Testing}

The toxicity of each test compound was evaluated using a variety of cancer cell lines and with human normal embryonic lung fibroblast (WI-38) and mouse embryo-fibroblast $(\mathrm{NIH} / 3 \mathrm{~T} 3)$ cell line as standards. Following a $24 \mathrm{~h}$ incubation period, the text compounds were added at concentrations ranging from 0.0032 to $32 \mathrm{microg} / \mathrm{mL}$ and allowed to incubate at $37^{\circ} \mathrm{C}$ with $5 \% \mathrm{CO}_{2}$ for $72 \mathrm{~h}$. Following incubation, Cell Titer-Blue reagent (Promega Corporation) was added ( $20 \mathrm{uL} / w e l l)$ and incubated for $2 \mathrm{~h}$. Fluorescence was determined at 530/590 $\mathrm{nm}$ and converted to \% cell viability versus control cells. 
All cytotoxicity values are calculated against a base-line value for each line that was generated from "mock-treatment" of the normal and tumor cell lines with media supplemented with all diluents used to prepare the chemotherapeutic compounds. For example, if the compounds were dissolved in DMSO and serial dilutions prepared in in Eagle's minimal essential medium, MEM, to treat the cells, then the mock-treated cells were "treated" with the same serial dilutions of DMSO without added chemotherapeutic compound. This was done to ensure that any cytotoxicity observed was due to the activity of the compound and not the diluents. For the studies reported here, the mocktreatment never resulted in a loss of cell viability of more than one percent, demonstrating that the activity observed was not due to cytotoxicity of any of the diluents used, but was due to activity of the tested compounds. When inhibition begins, the slop of the concentration/inhibition curve is steep until total inhibition occurs.

\section{RESULTS AND DISCUSSION \\ Product Yield and Chain Length}

Polymerization occurs through the interfacial polymerization process developed by

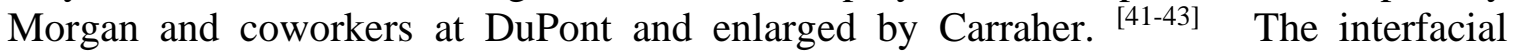
synthetic technique is employed industrially in the production of aramid fibers and polycarbonates. ${ }^{[44,45]}$ The rapidity of the reaction is a consequence of at least two factors. [44,45] First, the activation energy between acid chlorides and alcohols is about 20 $\mathrm{kcal} / \mathrm{mol}$ compared with the typical reaction between acids and diols of about 40 $\mathrm{kcal} / \mathrm{mol}$. Second, the rapid stirring enlarges the interfacial surface on the order of 10,000 time. The reaction is rapid being completed within 10 seconds.

Product yield and chain length are given in Table 1. Yields are generally moderate to good. The products from zirconocene and hafnocene are white, as expected since both reactants are white. The product from titanocene is cream to yellow colored because titanocene dichloride has two color sites. The $\mathrm{Ti}-\mathrm{Cl}$ is a bright red color that vanishes as the reaction occurs after about 10 seconds turning to a cream color from the Cp-Ti color site. The products are low to moderate polymers with chain lengths ranging from 260 for the zirconocene polymer to 1600 for the hafnocene product. We often find that yield is $\mathrm{Zr}=\mathrm{Hf}>\mathrm{Ti}$. The explanation for this is often in terms of the hard/soft concept where the yield becomes greater as the metal becomes softer.

41. Morgan PW. Condensation Polymers: By Interfacial and Solution Methods: NY; Wiley- Interscience, 1965.

42. Millich F, Carraher CE. Interfacial Synthesis. NY; Dekker, 1977.

43. Millich F, Carraher CE. Interfacial Synthesis. Vol. II. NY; Dekker, 1977.

44. Carraher CE. Polymer Chemistry, 10th edition. Taylor \& Francis, 2018.

45. Carraher CE. Introduction to Polymer Chemistry, 4th Ed. Tylor \& Francis, 2017.

Table 01: Product yield and chain length, degree of polymerization, DP for the product of metallocene dichlorides and isomannide. 


\begin{tabular}{|l|l|l|l|}
\hline Metallocene & Yield (\%) & Molecular Weight & DP \\
\hline $\mathrm{Cp}_{2} \mathrm{Ti}$ & 19 & & \\
\hline $\mathrm{Cp}_{2} \mathrm{Zr}$ & 42 & $1.2 \times 10^{5}$ & 260 \\
\hline $\mathrm{Cp}_{2} \mathrm{Hf}$ & 40 & $7.7 \times 105$ & 1,400 \\
\hline
\end{tabular}

The titanocene polymer is not sufficiently soluble to allow its molecular weight to be determined but it is sufficiently soluble to allow the cancer cell data to be determined since the solubility for cancer cell inhibition is much lower. The poor solubility of titanocene products is found for both monomeric and polymeric products and is typical for titanocene-containing compounds.

Titanocene dichloride has undergone Phase I clinical trials. The trials indicated a doselimiting side effect associated with nephrotoxicity and a number of unwanted physical side effects including nausea, reversible metallic taste, and pain during infusion, hypoglycemia, with these features undesirable. Counter, the absence of an effect on proliferative activity of the bone marrow, generally a dose-limiting side effect, was positive. Some phase II clinical trials were undertaken with patients with breast metastatic carcinoma ${ }^{[46]}$ and advanced renal cell carcinoma ${ }^{[47]}$ Unfortunately, low activity discouraged further clinical study. Further, lack of good solubility of titanocene compounds has hampered research with them.

\section{Infrared Spectral Results}

Infrared spectra were obtained for the monomers and products. Table 2 contains results of this spectroscopy emphasizing the bands associated with the metallocene moiety. All bands are given in wavenumbers. $\mathrm{CH}$ bands associated with the metallocene and thymidine are all present in the products as are other bands associated with both monomers. M-O bands are found at 420 and 345 below the capability of the employed instrumentation. Various scissoring, wagging and stretching bands derived from thymidine are observed. ${ }^{[48]}$ Bands derived from the metallocene are found associated with various stretching and modes. ${ }^{[21][24-26][28,29][35-38]}$ Thus, IR is consistent with the formation of the ether band.

\section{Thymidine- $\mathrm{Zr}$}

The ir spectral results are consistent with the proposed structure (Table )

\begin{tabular}{|l|l|l|l|l|}
\hline Assignment & $\mathrm{Cp}_{2} \mathrm{ZrCl}_{2}$ & Thymidine & $\mathrm{Cp}_{2} \mathrm{Zr} /$ Polymer & $\mathrm{Cp} 2 \mathrm{Hf} /$ Polymer \\
\hline C-H st & 3104 & & $\mathrm{a}$ & $\mathrm{a}$ \\
\hline C-H st & & $2995,2917,2859$ & $2996,2920,2860$ & $2964,2923,2852$ \\
\hline $\mathrm{C}=\mathrm{O}$ st & & 1664 & 1648 & 1648 \\
\hline C-O st & & 1513 & 1515 & 1516 \\
\hline Cp C-C st) & 1440 & & 1477 & 1443 \\
\hline C-C st & 1371 & & 1370 & 1370 \\
\hline CH rock & & 1352 & 1353 & 1352 \\
\hline M-O asy st & & & 1290 & 1280 \\
\hline
\end{tabular}




\begin{tabular}{|l|l|l|l|l|}
\hline $\mathrm{CH}$ rock & & 1277 & 1272 & 1269 \\
\hline $\mathrm{C}-\mathrm{CH}_{3}$ & & 1197 & 1200 & 1200 \\
\hline $\mathrm{Zr}-\mathrm{O}-\mathrm{C}$ & & & 1080 & 1080 \\
\hline $\mathrm{CH}_{3}$ rock & & 1069 & 1060 & 1050 \\
\hline $\mathrm{CH}$ ip wag & 1014 & & 1013 & 1012 \\
\hline $\mathrm{CH}$ op st & 873,827 & & 880,811 & 849,810 \\
\hline $\mathrm{Zr}-\mathrm{O}$ sym st & & & 724 & 730 \\
\hline
\end{tabular}

a. Obscured by a large band over the $3200-2600 \mathrm{~cm}^{-1}$ range

Bands derived from the zirconocene moiety are present as well as bands derived from the thymidine moiety.

Several M-O bands are possible including those from attachment to the R-C-O moieties. Further, there can be a variety of stretching, torsonal, etc. bands associated with the formation of the M-O moiety. The Zr-O asymmetric stretch appears at 1290 in the polymer. The $\mathrm{Zr}-\mathrm{O}$ symmetric stretch appears at 724 . A new band about 1080 is assigned to the $\mathrm{Zr}-\mathrm{O}-\mathrm{C}$ stretch. Thus, bands are present characteristic of the formation of the $\mathrm{Zr}-\mathrm{O}$ C linkage.

MALDI MS was carried out on the products over the general range of 2000 to $5000 \mathrm{Da}$ for the titanocene polymer and 500 to 5000 for the zirconocene polymer. All mass values are given in Da. Graphene from a simple number 2 pencil was employed at the matrix. It does not give major ion fragments above $500 \mathrm{Da}$ so it ideal for our use since we example the ion fragments that are give above $500 \mathrm{Da}$.

A portion of the MALDI MS for the zirconocene/thymidine polymer is given in Figure 3. Each of the metal-containing ion fragment clusters are clusters of ions that are produced because of the presence of titanium atom(s) within each cluster. Because titanium has isotopes, different ion fragments result that have the same structural formula but vary by the titanium isotope present. This creates what is often referred to as spectral "fingerprints" characteristic of the natural abundance of these isotopes. This will be discussed for the zirconium and hafnium-containing polymers. Even so, the metalcontaining fragments given in the following tables are clusters of such ion fragments. Table 3 contains the most abundant ions and ion fragment clusters given in Figure 3. Figure contains a MALDI $\mathrm{M}$ for the product of titanocene dichloride and zirconocene and table contains the assignments for the major ion fragments found for this product. The following abbreviations are employed in describing the ion fragment clusters where $\mathrm{U}$ is one unit, $2 \mathrm{U}$ is two units, $\mathrm{T}$ is thymidine minus two protons. Sodium is a common contaminant.

Ion fragment clusters to eleven units are found.

Zirconium has four isotopes with greater than 5\% relative abundance. Table 6 contains two isotopic abundance matches for ion fragment clusters containing a single zirconium atom. The matches are consistent with the presence of zirconium in the ion fragments. 


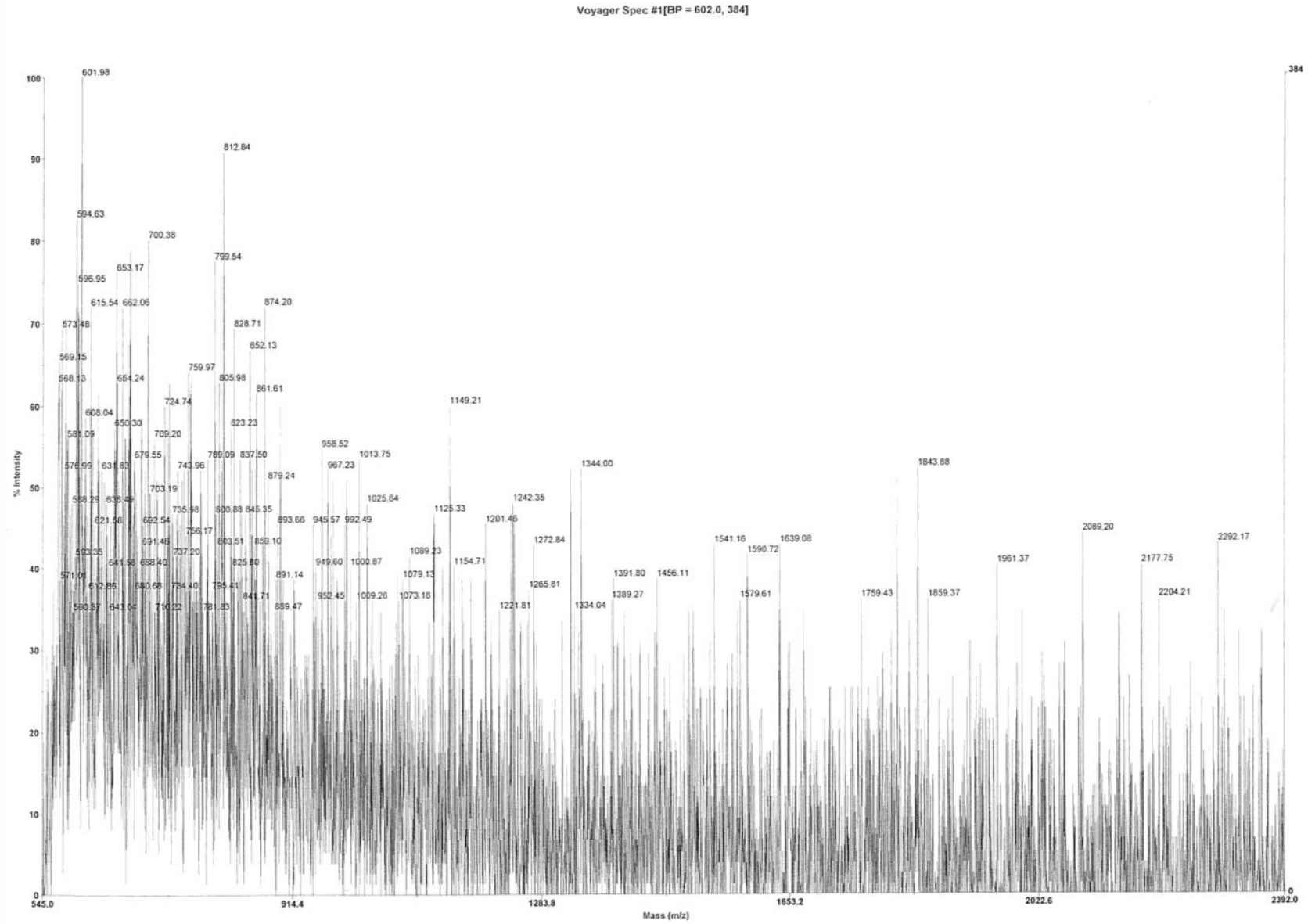

Figure 00. MALDI MS of the polymer from titanocene dichloride and thymidine over the approximate range of 550 to 2400 Da.

Table 03: Most abundant ion fragment clusters derived from the products of thymidine and zirconocene dichloride from 600 to $5500 \mathrm{Da}$.

\begin{tabular}{|l|l|l|l|l|}
\hline $\begin{array}{l}\text { (Tentative) } \\
\text { Assignment }\end{array}$ & Mass (Da) & & $\begin{array}{l}\text { (Tentative) } \\
\text { Assignment }\end{array}$ & Mass (Da) \\
\hline $\mathrm{U}+\mathrm{T}-2 \mathrm{O}$ & 662 & & $6 \mathrm{U}+\mathrm{Cp}_{2} \mathrm{Zr}$ & 2770 \\
\hline $\mathrm{U}+\mathrm{T}-\mathrm{O}$ & 680 & $6 \mathrm{U}+\mathrm{Cp}_{2} \mathrm{Zr}, 2 \mathrm{O}$ & 3016 \\
\hline
\end{tabular}




\begin{tabular}{|l|l|l|l|l|}
\hline $\mathrm{U}+\mathrm{T}$ & 700 & & $7 \mathrm{U}$ & 3230 \\
\hline $\mathrm{U}+\mathrm{T}, \mathrm{Na}$ & 724 & & $7 \mathrm{U}+\mathrm{Cp} 2 \mathrm{Zr}, 2 \mathrm{O}$ & 3479 \\
\hline $2 \mathrm{U}+\mathrm{CpZr}$ & 1079 & & $8 \mathrm{U}+\mathrm{Cp} 2 \mathrm{Zr}$ & 3905 \\
\hline $2 \mathrm{U}+\mathrm{T}-\mathrm{O}$ & 1148 & & $8 \mathrm{U}+\mathrm{Cp}_{2} \mathrm{Zr}, 2 \mathrm{O}$ & 3944 \\
\hline $3 \mathrm{U}+\mathrm{CpZr}$ & 1541 & & $9 \mathrm{U}+\mathrm{Cp} 2 \mathrm{Zr}, 2 \mathrm{O}$ & 4408 \\
\hline $4 \mathrm{U}$ & 1844 & & $10 \mathrm{U}+\mathrm{Cp} 2 \mathrm{Zr}$ & 4839 \\
\hline $4 \mathrm{U}+\mathrm{T}$ & 2089 & & $11 \mathrm{U}$ & 5075 \\
\hline $5 \mathrm{U}-\mathrm{O}$ & 2290 & & $11 \mathrm{U}+\mathrm{Cp}_{2} \mathrm{Zr}$ & 5295 \\
\hline $5 \mathrm{U}+\mathrm{Cp} 2 \mathrm{Zr}$ & 2541 & & & \\
\hline
\end{tabular}

Ion fragment clusters to eleven units in length are found.

Table 06: Isotopic abundance matches for two ion fragment clusters containing a single zirconium atom.

\begin{tabular}{|l|l|l|l|l|l|}
\hline Known Zr & \multicolumn{2}{l|}{ U+ T } & 2U+ T,Na \\
\hline Da & $\begin{array}{l}\text { Rel. } \\
\text { Abund. }\end{array}$ & Da & Rel. Abund & Da & Rel. Abund \\
\hline 90 & 100 & 700 & 100 & 724 & 100 \\
\hline 91 & 22 & 701 & 22 & 725 & 24 \\
\hline 92 & 33 & 702 & 35 & 726 & 34 \\
\hline 92 & 34 & 703 & 35 & 727 & 34 \\
\hline
\end{tabular}

Cell Inhibition Results

Much of our recent effort is the synthesis of potential drugs for the purpose of evaluation of structure/cancer activity building a catalogue of results that will assist in further syntheses. The cancer cells employed in the current study are given in Table .

The ability to inhibit cancer growth is generally obtained using two calculations. The first one measures the amount of material necessary to inhibit cell growth. The term effective concentration, EC, will be employed to describe this. The amount of material necessary to inhibit cell growth is then recorded. This measure is generally given in terms of inhibition as a function of compound concentration required to show 50\% inhibition, that is the concentration that induces a response halfway between the baseline and maximum after a specified exposure time. Table 10 contains the $\mathrm{EC}_{50}$ values found for the monomers and polymers. Cisplatin is used as a standard. Cisplatin is a widely employed drug used in the treatment of a variety of cancers including neck and head cancer, cervical cancer, breast cancer, bladder cancer, lung cancer, mesothelioma, brain tumors, ovarian cancer, testicular cancer, and neuroblastoma [29]. It is quite toxic with many unwanted side effects. Its generally high toxicity to tested cell lines is seen from its low $\mathrm{EC}_{50}$ values for the standard test cells here NIH-3T3 and WI-38 cells. 
Table 10: EC50 Concentrations (micrograms/mL) for the tested thymidine compounds. Values given in ( ) are standard deviations for each set of measurements.

\begin{tabular}{|c|c|c|c|c|c|}
\hline Sample & 3T3 & WI-38 & PANC-1 & AsPC-1 & PC3 \\
\hline $\mathrm{Cp}_{2} \mathrm{TiCl}_{2}$ & $1.8(.2)$ & $2.2(.1)$ & $0.45(.3)$ & $0.51(.05)$ & $0.48(.05)$ \\
\hline $\mathrm{Cp}_{2} \mathrm{Ti} / \mathrm{TH}$ & $0.040(.005)$ & $0.041(.005)$ & $0.026(.003)$ & $0.028(.003)$ & $0.039(.003)$ \\
\hline $\mathrm{Cp}_{2} \mathrm{ZrCl} 2$ & $1.8(.2)$ & $0.94(.1)$ & $0.38(.3)$ & $0.44(.05)$ & $0.25(.03)$ \\
\hline $\mathrm{Cp}_{2} \mathrm{Zr} / \mathrm{TH}$ & $0.045(.005)$ & $0.046(.005)$ & $0.0070(.003)$ & $0.0070(.005)$ & $0.0050(.003)$ \\
\hline $\mathrm{Cp}_{2} \mathrm{HfCl}{ }_{2}$ & $1.7(.2)$ & $1.2(.2)$ & $0.22(.2)$ & $0.18(.01)$ & $0.25(.03)$ \\
\hline $\mathrm{Cp}_{2} \mathrm{Hf} / \mathrm{TH}$ & $0.048(.005)$ & $0.043(.005)$ & $0.022(.003)$ & $0.014(.003)$ & $0.047(.003)$ \\
\hline Thymidine & $1.8(.5)$ & $1.7(.5)$ & $1.7(.5)$ & $1.8(.5)$ & $1.8(.05)$ \\
\hline Cisplatin & $0.015(.01)$ & $0.019(.01)$ & $.0023(.005)$ & $.0035(.005)$ & $0.0044(.004)$ \\
\hline
\end{tabular}

\begin{tabular}{|c|c|c|c|c|c|}
\hline Sample & MDA-MB & HT-29 & MCF-7 & U251 & G56 \\
\hline $\mathrm{Cp}_{2} \mathrm{TiCl}_{2}$ & $0.35(.05)$ & $0.54(.06)$ & $0.47(.05)$ & $>2.0$ & $>2.0$ \\
\hline $\mathrm{Cp}_{2} \mathrm{Ti} / \mathrm{TH}$ & $0.036(.003)$ & $0.024(.003)$ & $0.031(.003)$ & $14(, 07)$ & $120(.07)$ \\
\hline $\mathrm{Cp}_{2} \mathrm{ZrCl}{ }_{2}$ & $0.27(.03)$ & $0.31(.02)$ & $0.33(.05)$ & $>2.0$ & $>2.0$ \\
\hline $\mathrm{Cp}_{2} \mathrm{Zr} / \mathrm{TH}$ & $0.0090(.03)$ & $0.0040(.0003)$ & $0.0040(.0003)$ & $0.026(.03)$ & $0.035(.03)$ \\
\hline $\mathrm{Cp}_{2} \mathrm{HfCl}$ & $0.27(.03)$ & $0.31(.02)$ & $0.33(.05)$ & $>2.0$ & $>2.0$ \\
\hline $\mathrm{Cp}_{2} \mathrm{Hf} / \mathrm{TH}$ & $0.044(.003)$ & $0.029(.003)$ & $0.032(.003)$ & $0.062(.03)$ & $0.071(.03)$ \\
\hline Thymidine & $1.8(.05)$ & $1.8(.05)$ & $1.8(0.5)$ & $1.7(.5)$ & $1.8(.05)$ \\
\hline Cisplatin & $0.0029(.002)$ & $0.0041(.003)$ & $0.0057(.003)$ & $0.015(.01)$ & $0.021(.01)$ \\
\hline
\end{tabular}

It is seen that the $\mathrm{EC}_{50}$ values are in the nanogram- $\mathrm{mL}$ range which is considered outstanding. The polymers inhibit the growth of all human cancer cell lines.

Pancreatic cancer is generally an old-person's disease with the majority of cases occurring after 70 years of age. Symptoms include yellow skin, loss of appetite, back or abdominal pain, weight loss, dark urine and light-colored stools. Once it spreads there is no known cure and only pain control useful. There is no known good chemocare. This is the reason this is one of our focuses. In 2015 over 400,000 deaths were related to pancreatic cancer. The most common pancreatic cancer is pancreatic adenocarcinoma accounting for about $85 \%$ of the pancreatic cancers. The AsPC-1 pancreatic cancer cell line is used to evaluate the drugs ability to inhibit this type of cancer. The second cell line used in this study is the PANC-1 which is an epithelioid carcinoma pancreatic cell line, accounting for about $10 \%$ of the human pancreatic cancer cases. After pancreatic cancer is identified, about a quarter of the people survive for one year and 5\% last for five years. Early detection is more common because of the surge of NMRs taken for other reasons that identify the illness. The thymidine polymers offer good nanogram $/ \mathrm{mL}$ inhibition of both cancer cell lines. The fact that both levels of inhibition are similar for the AsPC-1 and PANC-1 cell lines might indicate that the drugs may inhibit other types of pancreatic cancer. 
The second focus is on brain cancer, in particular glioblastomas brain cancer, the deadliest of the brain cancers. Treatments include the same as most cancers' radiation, surgery, and chemotherapy. 25-29 The typical prognosis is not favorable with a fiveyear survival rate in the USA of about one third. The usual treatments have been recently reviewed by us.

25. Hart, MG, Garside, R, Rogers, G, Stein, K, Grant, R. Temozolomide for high grade glioma, Cochrane database of systemic reviews, (4), 2013.

26. Khosla, D. Concurrent therapy to enhance radiotherapeutic outcomes in glioblastoma, Annals translational medicine, 4(3) 54, 2016;

27. Stupp, R, Mason, WP, Van den Bent, MJ, Weller, M, Fisher, B, Taphoorn, MJB, Belanger, K, et. al. Radiotherapy plus concomitant and adjuvant temozolomide for glioblastoma multiforme. New England Journal Medicine 352(10):987-996, 2005. 28. Mason, WP, Mirimanoff, RO, Stupp, R. Radiotherapy with Concurrent and adjuvant temozolomide: A new standard of care for glioblastoma multiforme, Progress Neurotherapeutics and Neuropsychopharmacology, 1, 37-52, 2006.

29. Chamberlain, MC, Glantz, MJ, Chamlmers, L, Horm, A, Sloan, AE. Early necrosis following concurrent temodar and radiotherapy in patients with glioblastoma, Journal of Neuro-Oncology, 82(1), 81-83, 2006)

C. Carraher, M. Roner, J. Frank, F. Mosca, P. Slawek, L. Miller., Inhibition of human glioblastomas brain cancer cell lines by metal-containing polymers, WJPR 8(6), 123-139, 2019.

Two types of cell lines that are appropriate for studying glioblastoma cancer. The U251 is among the most often used. It was established at the Wallenberg laboratory, Uppsala, Sweden about 40 years ago. It was derived from human gliomas, derived from a male patient with malignant astrocytoma. G55 is a human glioblastoma (very aggressive) cell line that has been passed through nude mice and re-established as a stable xenograft cell line. The two cell lines each have unique levels of ATP and respond differently to assays with different tumorgenicity, mutations, and expressions of different genes. Studies show that G55 tends to be more invasive some believing that G55 models are more physiologically relevant because of greater invasiveness and migration since they form invasive intracranial tumors in rodents more characteristic of primary human GBM. Inhibition of both cell lines occurs at the nanogram $/ \mathrm{mL}$ level with is consider outstanding. It is interesting that the titanocene polymer while inhibiting the glioblastoma cancer cells they do so at a much higher concentration than the $\mathrm{Zr}$ and $\mathrm{Hf}$ polymers. Thus, of the three polymers, the Ti polymer should be considered the least to be used in brain cancer testing.

Another emphasis is breast cancer. While there is much progress related to breast cancer in 2012 there were about 1.7 million new cases reported with over one half million deaths. It is much more common among women than men, but suspicious lumps in the breast area should be medically inspected regardless of sex. Survival rates are on the increase for developed countries with over $80 \%$ survival rates for five years. The two cancer cell lines employed by us are appropriate again representing the most forms of breast cancer. They represent a matched pair of cell lines. The MDA-MB-231 (strain number 7233) cells are estrogen-independent, estrogen receptor negative while the MCF- 
7 (strain line 7259) cells are estrogen receptor (ER) positive. Again, the polymers exhibit good inhibition of both cell line types in the nanogram $/ \mathrm{mL}$ range. The polymers also show good inhibition of the prostrate, lung and colon cancer cell lines. Thus, good inhibition of all the cancers is found.

C. Carraher, M. Roner, K. Shahi, A. Moric-Johnson, L. Miller, P. Slawek, F. Mosca. Control of breast cancer using metal-containing polymers based on cell line results, Annals of Breast Cancer, 1 (1003), 1-9, 2018

The second approach in determining the effectiveness of cancer inhibition is the measure of how well the compound differentiates between inhibition of the test cell lines and standard cell line. The term chemotherapeutic index, CI, is often used for this measure. Thus, the $\mathrm{CI}_{50}$ is the ratio of the $\mathrm{EC}_{50}$ for the $\mathrm{NIH} / 3 \mathrm{~T} 3$ or WI- 38 cells divided by the $\mathrm{EC}_{50}$ for the particular test cell line given in Table . Since it is generally accepted that WI-38 results are better at indicating ability of the tested compounds to prevent cancer growth in animals, and finally humans, $\mathrm{CI}_{50}$ values based on only WI-38 cells are presented in Table 11. Large values are desired since it indicates that there is a preference for inhibiting the cancer cell lines in comparison to the standard cells. For the present polymers, $\mathrm{CI}_{50}$ values are generally greater than one. The lowest values are found for the glioblastomas brain cancer cells. Such brain cells generally exhibit the lowest values found for the tested cell lines. Even so, the $\mathrm{Zr}$ polymer shows decent $\mathrm{CI}_{50}$ values. Further, while cisplatin is employed in the treatment of glioblastomas brain cancer, the $\mathrm{CI}_{50}$ values for the $\mathrm{Zr}$ polymer is much larger compared to cisplatin and the $\mathrm{Hf}$ polymer in the same range as cisplatin. .

Table $\mathrm{CI}_{50}$ values for the thymidine/metallocene compound.

\begin{tabular}{|c|c|c|c|c|}
\hline Sample & $\begin{array}{l}\text { EC }_{50} \text { WI-38/ } \\
\text { EC50PNC-1 }\end{array}$ & $\begin{array}{l}\text { EC }_{50} \mathrm{WI}-38 / \\
\text { EC } \\
50 \text { AsPC-1 }\end{array}$ & $\begin{array}{c}\text { EC }_{50} \mathrm{WI}-38 / \\
\text { EC }_{50} \mathrm{PC}-3\end{array}$ & $\begin{array}{c}\text { EC }_{50} \mathrm{WI}-38 / \\
\text { EC }_{50} \mathrm{MDA}\end{array}$ \\
\hline $\mathrm{Cp}_{2} \mathrm{TiCl}_{2}$ & 4.9 & 4.3 & 4.6 & 6.3 \\
\hline $\mathrm{Cp}_{2} \mathrm{Ti} / \mathrm{TH}$ & 1.6 & 1.5 & 1.1 & 1.1 \\
\hline $\mathrm{Cp}_{2} \mathrm{ZrCl}_{2}$ & 2.5 & 2.1 & 3.8 & 3.5 \\
\hline $\mathrm{Cp}_{2} \mathrm{Zr} / \mathrm{TH}$ & 6.6 & 6.6 & 9.2 & 5.1 \\
\hline $\mathrm{Cp}_{2} \mathrm{HfCl}_{2}$ & 5.5 & 6.7 & 4.8 & 4.4 \\
\hline $\mathrm{Cp}_{2} \mathrm{Hf} / \mathrm{TH}$ & 2.0 & 3.1 & 0.92 & 1.0 \\
\hline Cisplatin & 8.3 & 5.4 & 4.4 & 6.6 \\
\hline
\end{tabular}

\begin{tabular}{|c|c|c|c|c|}
\hline Sample & $\begin{array}{l}\text { EC }_{50} \text { WI-38I } \\
\text { EC }_{50} \mathrm{HT}-29\end{array}$ & $\begin{array}{l}\text { EC }_{50} \text { WI-38/ } \\
\text { EC }_{50} \text { MCF-7 }\end{array}$ & $\begin{array}{c}\mathrm{EC}_{50} \mathrm{WI}-38 / \\
\mathrm{EC}_{50} U 251\end{array}$ & $\begin{array}{c}\text { EC }_{50} W I-381 \\
\text { EC }_{50} G 55\end{array}$ \\
\hline $\mathrm{Cp}_{2} \mathrm{TiCl}_{2}$ & 4.1 & 4.7 & $<0.62$ & $<0.62$ \\
\hline $\mathrm{Cp}_{2} \mathrm{Ti} / \mathrm{TH}$ & 1.7 & 1.3 & 0.003 & 0.0003 \\
\hline $\mathrm{Cp}_{2} \mathrm{ZrCl}_{2}$ & 3.0 & 2.8 & $<0.47$ & $<0.47$ \\
\hline $\mathrm{Cp}_{2} \mathrm{Zr} / \mathrm{TH}$ & 12 & 12 & 1.8 & 1.3 \\
\hline $\mathrm{Cp}_{2} \mathrm{HfCl}_{2}$ & 3.9 & 3.6 & $<0.60$ & $<0.60$ \\
\hline $\mathrm{Cp}_{2} \mathrm{Hf} / \mathrm{TH}$ & 1.5 & 1.3 & 0.70 & 0.61 \\
\hline Cisplatin & 4.6 & 3.3 & 0.80 & 0.57 \\
\hline
\end{tabular}


